\title{
Assessing and Projecting Surface Air Temperature Conditions Required To Sustain Permafrost in Japan
}

Tokuta Yokohata ( $\nabla$ yokohata@nies.go.jp )

National Institute for Environmental Studies

Go IWAHANA

University of Alaska Fairbanks

Kazuyuki Saito

Japan Agency for Marine-Earth Science and Technology

Noriko Ishizaki

National Institute for Environmental Studies

Taiga Matsushita

University of Tsukuba

Tetsuo Sueyoshi

National Institute for Polar Research

\section{Research Article}

Keywords: temperature, Hemisphere, mountainous

Posted Date: September 15th, 2021

DOI: https://doi.org/10.21203/rs.3.rs-880162/v1

License: (9) (i) This work is licensed under a Creative Commons Attribution 4.0 International License.

Read Full License 
1 Assessing and projecting surface air temperature conditions required to sustain permafrost in

2 Japan

3

$4 \quad$ Tokuta Yokohata ${ }^{\mathrm{a}}$, yokohata@nies.go.jp

5 Go Iwahana ${ }^{\mathrm{b}}$, giwahana@alaska.edu

$6 \quad$ Kazuyuki Saito ${ }^{\mathrm{c}}$, ksaito@jamstec.go.jp

$7 \quad$ Noriko Ishizaki ${ }^{a}$, ishizaki.noriko@nies.go.jp

$8 \quad$ Taiga Matsushita ${ }^{\mathrm{d}}$, s2121147@s.tsukuba.ac.jp

9 Tetsuo Sueyoshi ${ }^{\mathrm{e}}$, sueyoshi.tetsuo@nipr.ac.jp

10

11 a National Institute for Environmental Studies, Tsukuba, Japan

$12{ }^{\mathrm{b}}$ University of Alaska Fairbanks, Alaska, USA

13 ' Japan Agency for Marine-Earth Science and Technology, Yokohama, Japan

$14{ }^{\mathrm{d}}$ University of Tsukuba, Tsukuba, Japan

$15 \quad{ }^{\mathrm{e}}$ National Institute for Polar Research, Tokyo, Japan

\section{Abstract}

Permafrost covers a wide area of the Northern Hemisphere, including high-altitude mountainous areas even at mid-low latitudes. There is concern that the thawing of mountain permafrost can cause slope instability and substantially impact alpine ecosystems. However, permafrost in mountainous areas is difficult to observe, and detailed analyses have not been performed on its current distribution and future changes. Here, we show that the surface air temperature required to sustain Japan's mountain permafrost is estimated to decrease rapidly at present; most mountain permafrost in Japan is projected to disappear by the second half of the 21 st century, and disappear very quickly in some places from approximately 2020-2030, regardless of climate scenarios. Our projections indicate that climate change has a considerable impact on mountain environments and that even if climate stabilization is achieved, Japan's mountain permafrost may almost disappear. It is important to consider measures to adapt to the changing mountain environment. 
32 The ground where the temperature falls below $0^{\circ} \mathrm{C}$ for two consecutive years is called permafrost ${ }^{1}$.

33 Thawing of permafrost in mountainous areas has reportedly increased the frequency and scale of 34 rockfalls and landslides ${ }^{2-4}$. This increase in disasters in mountainous areas threatens the safety of hikers 35 and mountaineers ${ }^{5}$ and changes iconic mountaineering routes and suitable climbing seasons ${ }^{6}$. In addition, the thawing of permafrost has a substantial impact on alpine ecosystems through changes in temperature, soil moisture and groundwater ${ }^{7}$. The disappearance of permafrost, coupled with inadequate precipitation in summer and reduced snowmelt, can cause a lack of water during the growing season, early peak times, changes in species compositions, and reduced greening and productivity $^{8,9}$. Thawing of mountain permafrost can have great impacts on mountain ecosystems, including various kinds of alpine plants and animals ${ }^{10}$, which are valuable natural resources visited by many climbers ${ }^{11}$.

43 Studies on future projections of permafrost thawing show that thawing proceeds from lower latitudes 44 and warmer regions ${ }^{12}$. Therefore, it is very important to estimate the current state and future projection of permafrost located at the lower limit latitude of the permafrost distribution to understand the changes in permafrost due to climate change. According to a study of global permafrost distribution ${ }^{13}$, the lowest latitude permafrost in the Northern Hemisphere is located on the Tibetan Plateau $\left(28^{\circ} \mathrm{N}\right)$. In Asia, Japan's mountainous areas (Mt. Fuji: $35^{\circ} \mathrm{N}$, Mt. Tateyama: $37^{\circ} \mathrm{N}$, and the Daisetsu Mountains: $\left.43^{\circ} \mathrm{N}\right)$, the Tianshan Mountains in China $\left(42^{\circ} \mathrm{N}\right)$, and the Daxing Anling Mountains $\left(50^{\circ} \mathrm{N}\right)$ reportedly contain permafrost ${ }^{13}$. Among these areas, estimates of permafrost distribution at the 1-km scale have been compared with observational data for the Tibetan Plateau and mountains in China ${ }^{13}$. On the other hand, regarding Japan's mountain permafrost, permafrost has been reported in the Daisetsu Mountains ${ }^{14,28-31}$, Mt. Fuji ${ }^{15,16}$, and Mt. Tateyama ${ }^{17,18}$ in the Northern Japan Alps, but country-scale analyses have not been performed to date.

Future projections of permafrost distribution have been estimated using global climate models $(\mathrm{GCMs})^{19-22}$. However, since the resolution of GCMs is approximately $100 \mathrm{~km}$ in general, it is difficult to estimate the current distribution and future projection of mountain permafrost, which involves detailed altitude distributions ${ }^{23}$. In a previous study, we used bias-corrected and 1-km downscaled GCM projections ${ }^{24}$ to assess the size of the areas where climate conditions are suitable for permafrost in Japan's Daisetsu Mountains ${ }^{25}$. In this study, the areas with climatic conditions suitable for sustaining permafrost in all of Japan were estimated by using the method from our previous study ${ }^{25}$. 


\section{Assessing surface air temperature conditions to sustain permafrost in Japan}

65 Figure 1 (left) shows the altitude distribution of eastern Japan. In general, the annual mean surface air 66 temperature is low at high latitudes and high altitudes. The correspondence between altitude and annual mean surface air temperature is shown in Figure S1. In eastern Japan, the regions with low surface air temperatures are on Hokkaido (the northern island in Japan). As shown in Figure 1 left, high-altitude mountains exist in the inland (Daisetsu Mountains, 1 in Figure 1 right), southern central (Hidaka Mountains, 2 in Figure 1 right), and eastern areas (5, 6, and 8 in Figure 1 right) on Hokkaido. On the main island on the south side of Hokkaido, there are particularly high mountains in the central region, called Chubu (southern square in Figure 1 left), due to the influence of orogeny. In the Chubu region, the high mountainous areas are the Northern Japan Alps ( 3 in Figure 1 right), the Southern Alps (7 in Figure 1 right), and Mt. Fuji (4 in Figure 1 right).

Figure 1 (right) shows an area with climatic conditions that are suitable for permafrost development in the mountainous region of Japan. These areas are probable locations of permafrost based on nine bias-corrected and downscaled climate scenarios ${ }^{24,26}$ in each grid. Permafrost classification in this study is based on Saito et al. ${ }^{27}$, which classified permafrost into two types (i.e., climate-driven permafrost (CDP) and environmentally conditioned permafrost (ECP); see details in the Methods section); however, only ECP is present in the mountainous region of Japan. Given that the actual distribution of permafrost is determined by complex interactions between environmental phenomena, such as topography and geology $y^{14}$, the grid cells classified as permafrost in this study indicate only where the climatic conditions are suitable for the maintenance of permafrost. We refer to areas containing these grid cells as the "ECP region". In addition to surface air temperature, snow cover is an important factor affecting the distribution of permafrost ${ }^{14}$. In general, permafrost is distributed in wind-blown gravel areas where the snow cover is typically thin. Due to the limited distribution of wind-blown gravel areas, the actual distribution of permafrost would be smaller than the area estimated using only surface air temperatures ${ }^{25}$.

The ECP regions obtained by this study, in descending order by area under the current climate, are 1) the Daisetsu Mountains, 2) the Hidaka Mountains, 3) the Northern Japan Alps, 4) Mt. Fuji, 5) Mt. Shiretokodake, 6) Mt. Sharidake, 7) the Southern Japan Alps, 8) Mt. Akandake, and 9) Mt. Yotei. In general, the ECP region is located in high-latitude and high-altitude mountainous regions where the surface air temperature is low throughout the year. 

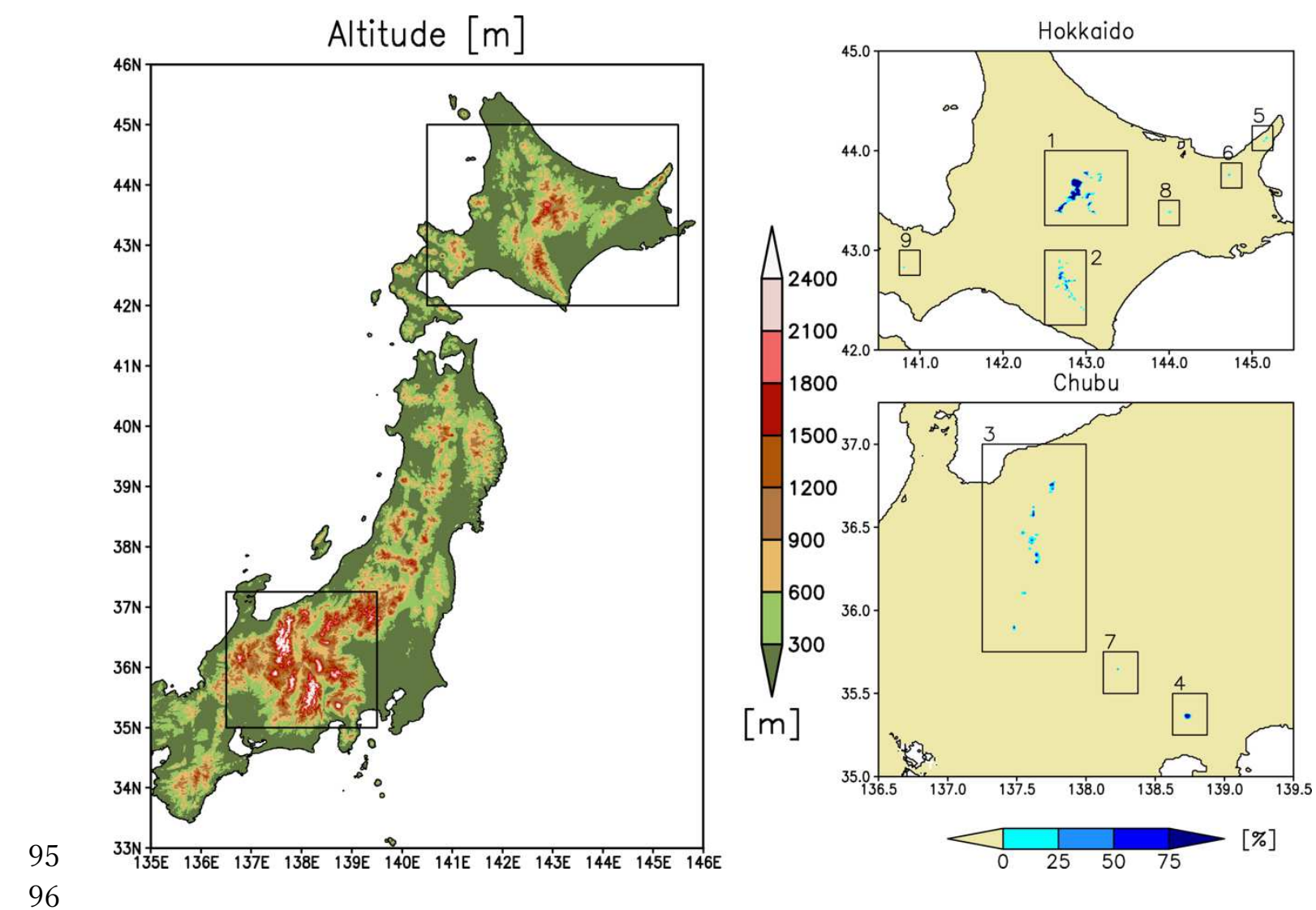

Figure 1. Left) The altitude distribution of the eastern Japan region [m], and right) the distribution of the surface air temperature environment that maintains permafrost in the mountainous regions of Japan, upper right) Hokkaido, and lower right) the Chubu region. The numbers indicate 1) Daisetsu Mountains, 2) Hidaka Mountains, 3) Northern Japan Alps, 4) Mt. Fuji, 5) Mt. Shiretokodake, 6) Mt. Shari, 7) Southern Japan Alps, 8) Mt. Akandake, and 9) Mt. Yotei. The surface air temperature environment is derived based on the probability determined based on nine bias-corrected climate scenarios. The Grid Analysis and Display System (GrADS, http://cola.gmu.edu/grads/) is used to plot this figure.

Figure 2 shows the details of the ECP region in the nine areas. Regions with high confidence in multimodel estimations (large value in Figure 2) are 1) the Daisetsu Mountains, 2) the Hidaka Mountains, 3) the Northern Japan Alps, and 4) Mt. Fuji. In Figure 2, the points where permafrost was confirmed by previous observational studies are shown in red (the details of the observational sites are shown in Supplementary Table S1). Permafrost has been observed in the Daisetsu

112 Mountains ${ }^{14,28-31}$, Northern Japan Alps ${ }^{17}$, and on Mt. Fuji ${ }^{16}$, which is consistent with the findings of 113 the present study, as shown in Figure 2. The ECP region exists at altitudes higher than $1600 \mathrm{~m}$ in the 114 Daisetsu and Hidaka Mountains on Hokkaido. Permafrost has not been observed in the Hidaka 
115 Mountains to date, but our results indicate that permafrost can exist at altitudes higher than $1600 \mathrm{~m}$

116 in the Hidaka Mountains. Permafrost has been observed in Tateyama in the Northern Japan Alps ${ }^{17,18}$,

117 but permafrost can exist in other mountains at altitudes above $2600 \mathrm{~m}$. Mt. Fuji is located at a lower

118 latitude than other areas, but the area above $3000 \mathrm{~m}$ is identified as the ECP region, which is

119 consistent with previous studies ${ }^{16}$. We also confirmed that the annual mean surface air temperature at

120 the field observation sites in these mountains is consistent with the observational data, as shown in

121 Supplementary Figure S2.

122 Regions with low confidence in projections from multiple bias-corrected and downscaled GCMs

123 are 5) Mt. Shiretokodake, 6) Mt. Sharidake, 7) the Southern Japan Alps, 8) Mt. Akandake, and 9) Mt.

124 Yotei (Figure 2). In these domains, ECP regions exist at altitudes above $1400 \mathrm{~m}$ (Mt. Shiretokodake),

$1251200 \mathrm{~m}$ (Mt. Sharidake), $3000 \mathrm{~m}$ (Southern Japan Alps), $1300 \mathrm{~m}$ (Mt. Akandake), and $1800 \mathrm{~m}$ (Mt.

126 Yotei).

127 Latitude and altitude are important geographical factors that determine the surface air temperature

128 and thus the distribution of permafrost. Figure 3 shows a scatter plot of the latitude-altitude distribution

129 in the ECP regions under the present climate. In Figure 3, the regression line is calculated by selecting

130 the points corresponding to the lowest altitude at each latitude. Thus, the lower limit altitude of the

131 ECP region in the mountainous region of Japan in the present climate is

Altitude $=2997-($ latitude -35$) \times 177$ [m] (1)

133 The lower limit altitude is approximately $2997 \mathrm{~m}$ at latitude $35^{\circ} \mathrm{N}$, and the lower limit altitude

134 decreases by $177 \mathrm{~m}$ as the latitude increases by $1^{\circ}$.

135 
1) Daisetsu Mountains

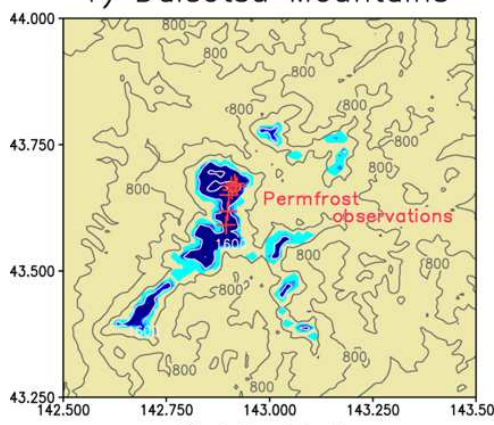

4) Mt. Fuji

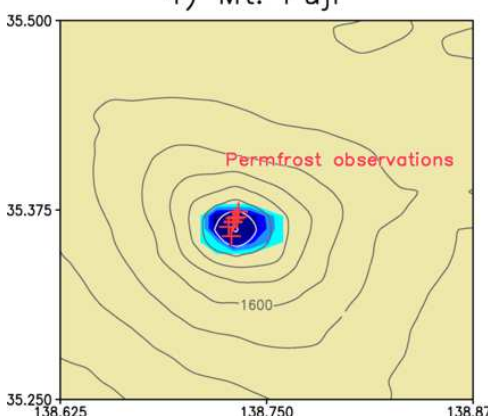

7) South Japan Alps

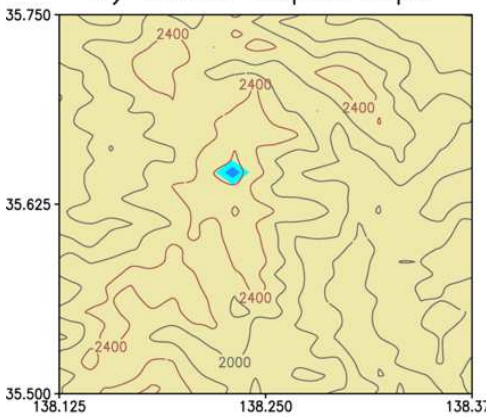

2) Hidaka Mountains

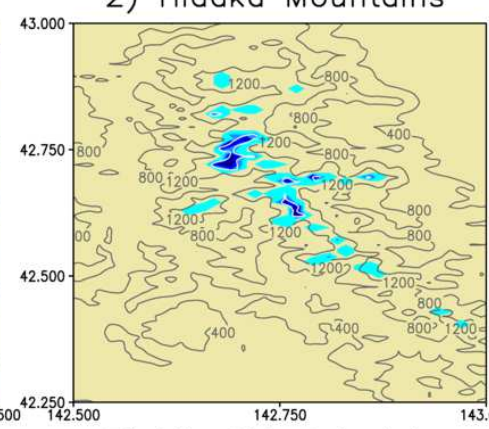

5) Mt. Shiretokodake

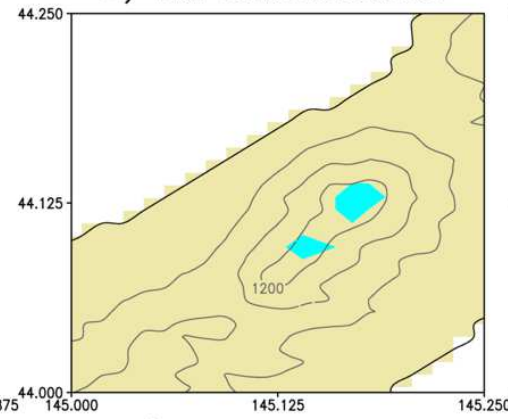

8) Mt. Akandake

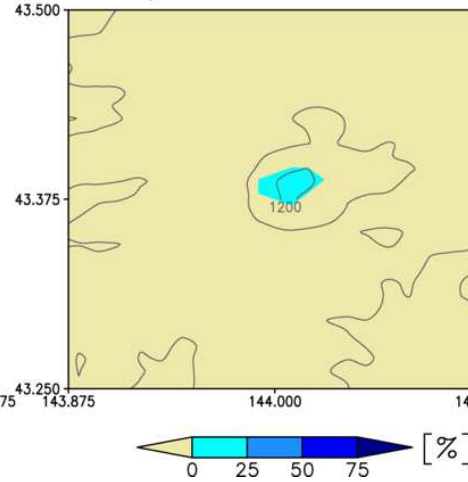

3) North Japan Alps

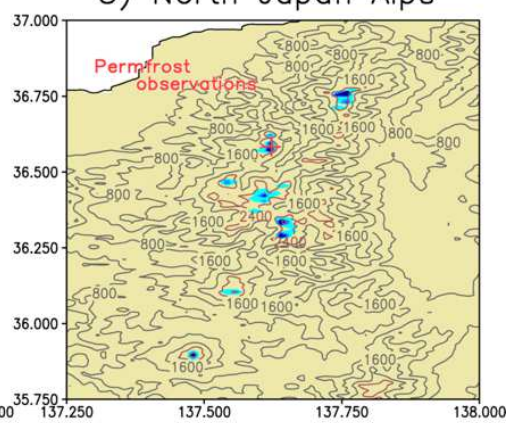

6) Mt. Sharidake

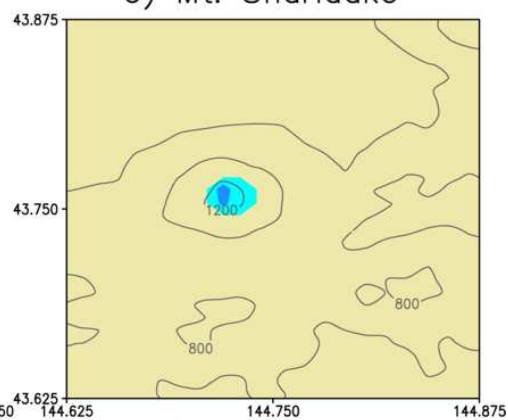

9) Mt. Youtei

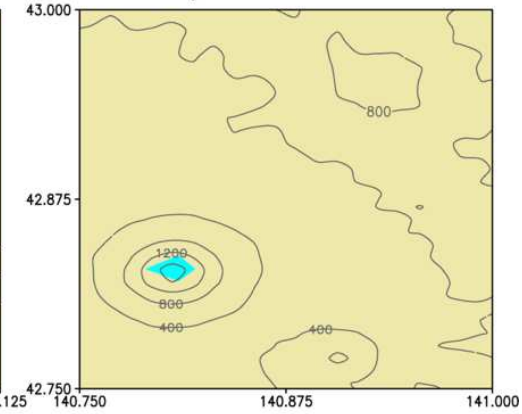

Figure 2. Distribution of the surface air temperature environment that maintains permafrost in the mountainous regions of Japan under the current climate (averaged over 1999-2018). 1) Daisetsu Mountains, 2) Hidaka Mountains, 3) Northern Japan Alps, 4) Mt. Fuji, 5) Mt. Shiretokodake, 6) Mt. Shari, 7) Southern Japan Alps, 8) Mt. Akandake, and 9) Mt. Yotei. The environmentally conditioned permafrost $(\mathrm{ECP})$ region is derived based on the probability determined based on nine bias-corrected climate scenarios. Red points indicate places where permafrost has been observed (see Supplementary Table S1). The Grid Analysis and Display System (GrADS, http://cola.gmu.edu/grads/) is used to plot this figure. 


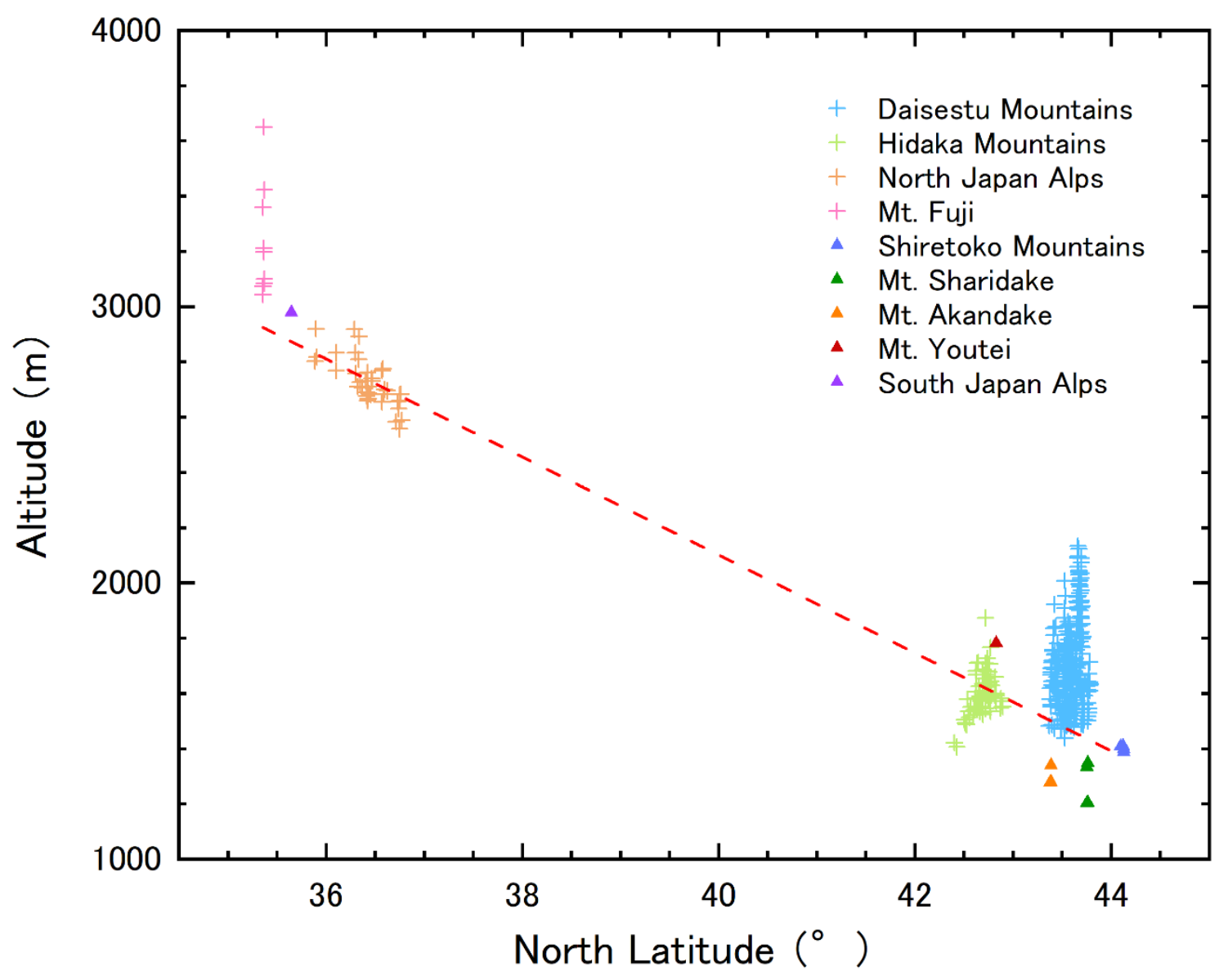

150 Figure 3. Latitude-altitude distribution of the surface air temperature environment that maintains 151 permafrost. The colours or shapes differ for each of the nine regions shown in Figure 1. The red line 152 is a regression line calculated using the points that take the lowest altitude at each latitude.

\section{Projecting surface air temperature conditions to sustain permafrost in Japan}

156 Figure 4 shows the time series of the area of ECP regions in Japan. Similar to Figure 2, Figure 4 shows the results of the nine domains in order from the one with the largest ECP region under the current climate. In the Daisetsu Mountains, which have the largest ECP region in Japan, the results are similar to those of our previous study ${ }^{25}$. ECP regions decrease from approximately 2000 because the surface air temperature at high latitudes rises sharply from this period in the GCM projections (Figure 7 in Yokohata et al. ${ }^{25}$ ). In the Daisetsu Mountains, the area of the ECP region was approximately $150 \mathrm{~km}^{2}$ in 2010, but the average value of multimodel projections shows that the ECP region disappears in approximately 2070 under RCP8.5. In 2100, the ECP region is projected to decrease to $20 \mathrm{~km}^{2}$ in the

164 RCP2.6 scenario and $10 \mathrm{~km}^{2}$ in the RCP4.5 scenario. In the Hidaka Mountains and Northern Japan 
166 of the ECP region peaked in approximately 2000, after which the ECP region decreased sharply. In 167 the Hidaka Mountains and Northern Japan Alps, the differences among climate scenarios are very 168 small, and in all scenarios, the ECP regions are projected to disappear by approximately 2030. The 169 reason why the ECP regions of the Hidaka Mountains and Northern Japan Alps are projected to 170 disappear in the near future is that the elevations of these mountains are close to the lower limit of the 171 ECP region under the current climate (Figure 3). The ECP regions are easily lost in the Hidaka 172 Mountains and Northern Japan Alps due to the rapid increase in surface temperature in the high173 latitude regions, which has progressed since the 2000s (Figure 7 in Yokohata et al. ${ }^{25}$ ).

174 Compared with other regions, Mt. Fuji has a relatively small change in the area of its ECP region 175 (Figure 4) because there is a large difference between the mountaintop altitude and the lower limit 176 altitude of the ECP region under the current climate (Figure 3). Nevertheless, the ECP region on Mt. 177 Fuji is projected to disappear completely by 2100 in the RCP8.5 scenario. The ECP region on Mt. Fuji 178 as of 2010 was approximately $8 \mathrm{~km}^{2}$, and it is projected to be approximately $1 \mathrm{~km}^{2}$ in the RCP4.5 179 scenario and approximately $2 \mathrm{~km}^{2}$ in the RCP2.6 scenario in 2100 . Even if climate stabilization is 180 achieved in the RCP2.6 and RCP4.5 scenarios, it is projected that the Mt. Fuji ECP region will nearly 181 disappear by the end of the $21^{\text {st }}$ century.

182 In the five domains with low concordance of multimodel projections for ECP regions under the 183 current climate (20\% or less), including 5) Mt. Shiretoko, 6) Mt. Shari, 7) the Southern Alps, 8) Mt. 184 Akan, and 9) Mt. Yotei, the ECP regions are projected to decrease rapidly beginning in the 2000s 185 (Figure 4). In these domains, the ECP region is projected to disappear rapidly because the lower limit 186 altitude of the ECP region in the current climate is close to the mountain altitude, as shown in Figure 187 3, and because the areas of the ECP region in the current climate are small (approximately $1-4$ grids, 188 where 1 grid is approximately $1 \mathrm{~km}^{2}$ ).

189 The time series of the area of ECP regions in all of Japan is shown in Figure 4. Compared with the 190 future projections for the Daisetsu Mountains shown in our previous study ${ }^{25}$, the projected decrease in 191 the ECP region throughout Japan is more rapid because the altitudes of many mountains other than 192 the Daisetsu Mountains and Mt. Fuji are close to the lower limit altitudes of the ECP region under the 193 current climate, and the ECP region disappears due to a slight temperature increase.

194 

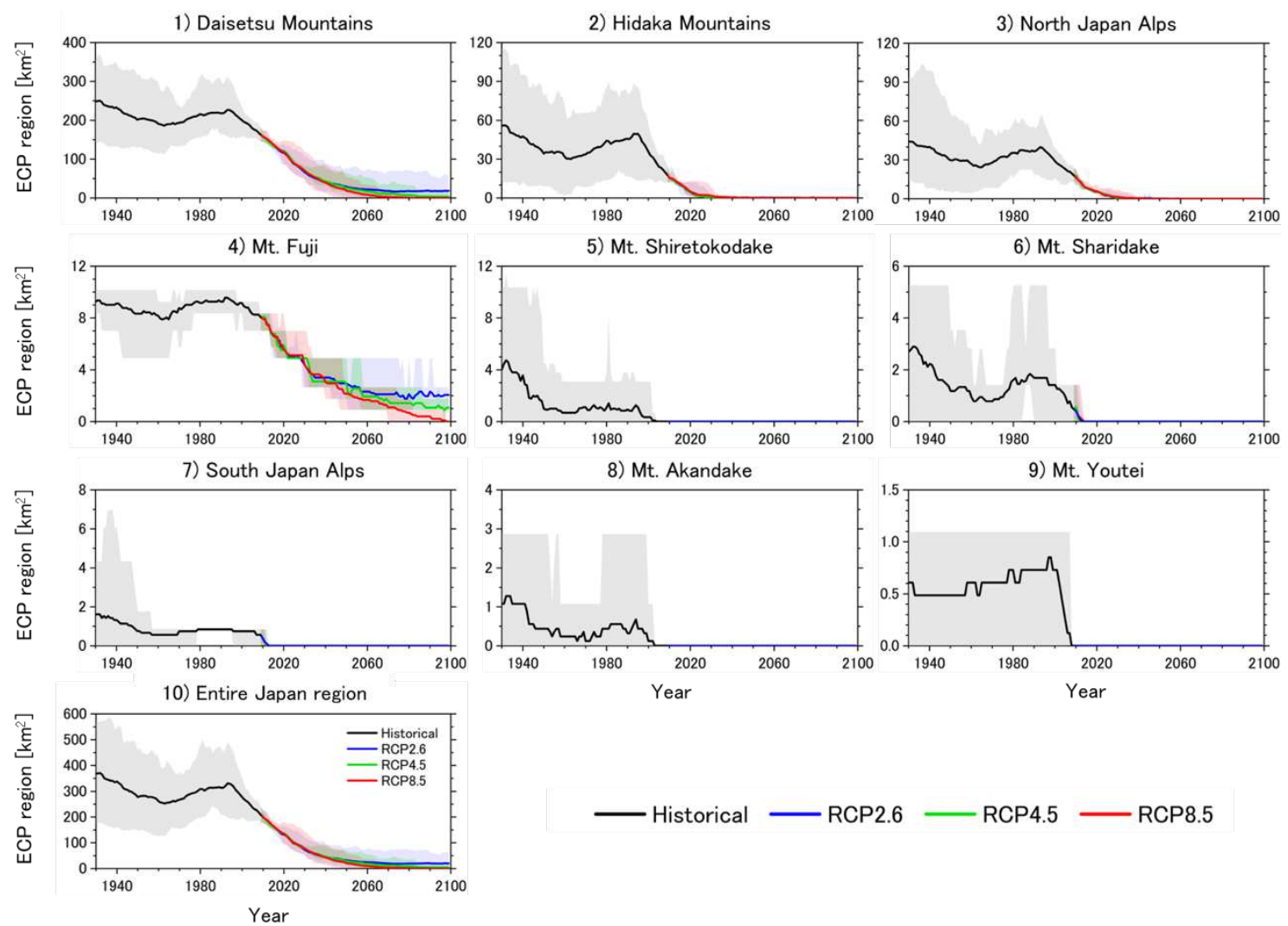

Figure 4. Time sequence of the surface air temperature environment area that maintains permafrost in the mountainous regions of Japan. 1) Daisetsu Mountains, 2) Hidaka Mountains, 3) Northern Japan Alps, 4) Mt. Fuji, 5) Mt. Shiretokodake, 6) Mt. Shari, 7) Southern Japan Alps, 8) Mt. Akandake, 9) Mt. Yotei, and 10) all of Japan. Historical simulations (black) and future projections of the RCP2.6 (blue), RCP4.5 (green), and RCP8.5 (red) scenarios are shown. The shading indicates the minimum and maximum of multimodel projections, and the thick line shows the multimodel average.

\section{Conclusions}

206 In previous studies, the existence of permafrost was reported only in the Daisetsu Mountains ${ }^{14,28-31}$, 207 Mt. Fuji ${ }^{15,16}$, and Mt. Tateyama ${ }^{17,18}$ in the Northern Japan Alps of Japan, but this study shows that 208 permafrost can exist in other regions, such as the Hidaka Mountains, Mt. Shiretokodake, Mt. Sharidake, 209 the Southern Japan Alps, Mt. Akandake, and Mt. Yotei (Figure 2). Our results will aid in the selection 210 of candidate sites for mountain permafrost observations in Japan. If permafrost exists in these regions, 211 then monitoring changes in permafrost is an important future task.

212 Furthermore, for the first time, this study shows future projections of the surface air temperature 213 environment that maintains permafrost (called the ECP region) throughout Japan. We project that most 214 of the ECP region in Japan will disappear by the second half of the 21st century, regardless of climatic 
215 scenarios (Figure 4). The temperature environment that maintains permafrost currently exists in nine

216 domains (Figure 2), but it is projected that even in the RCP2.6 scenario, which stabilizes the global

217 average temperature at an increase of approximately $2{ }^{\circ} \mathrm{C}$, the ECP regions can exist only at altitudes

218 higher than $1900 \mathrm{~m}$ in the Daisetsu Mountains and higher than $3200 \mathrm{~m}$ on Mt. Fuji in 2100 (Figure

219 S3). Our results indicate that climate change is already having a tremendous impact on Japan's

220 mountain environment and that even if climate stabilization can be achieved, mountain permafrost is

221 projected to largely disappear.

222 Notably, the analysis presented in this study does not consider detailed factors, such as topography

223 (slope direction and slope angle), soil properties (porosity and permeability), and meteorological

224 conditions (precipitation, local wind direction and snow cover), which are known to play important

225 roles in determining the distribution of permafrost ${ }^{14,16-18,28}$. Using a 30-year average as the

226 calculation period for the freezing and thawing indices, hysteresis in surface air temperature changes

227 is considered in our estimates for the ECP region (see Methods). However, the response of

228 permafrost to changes in climatic conditions may occur over a much longer time scale ${ }^{27}$, and

229 changes in permafrost distributions may be slower than those shown in Figure 4. Nonetheless, the

230 extent of permafrost in Japan's mountainous areas is projected to decrease significantly due to future

231 rises in temperature.

232 The climatic conditions under which permafrost can exist in Japan's mountainous regions are

233 projected to shift towards conditions where permafrost will disappear, regardless of the climate

234 scenario (RCP2.6, RCP4.5, and RCP8.5), indicating the importance of monitoring the environment

235 and developing adaptation measures for climate change. Specifically, it is important to monitor the

236 phenology and distribution of alpine vegetation to investigate the effects of permafrost thawing on

237 alpine ecosystems ${ }^{25}$. Accurately monitoring environmental changes in mountainous areas is also vital

238 to address the problem of increases in the scale and frequency of flow slopes and landslides ${ }^{2,-4}$. Thus,

239 applying a technique to understand the ground-surface displacement in detail by using satellite data

240 is effective $\mathrm{e}^{32,33}$. In addition to accurately monitoring changes in mountain environments, providing

241 local governments with appropriate measures to prepare for major future environmental changes is

242 an essential issue for future studies.

243

\section{Methods}

\section{Bias-corrected and downscaled climate model output}

246 In this study, we used bias-corrected and downscaled climate model outputs developed by Ishizaki et

247 al. ${ }^{24,26}$, who generated two bias-corrected climate scenarios using different methods. We used

248 climate scenarios based on the cumulative distribution function-based downscaling method

249 (CDFDM, developed in previous studies ${ }^{34-36}$ ). Using the CDFDM, the cumulative distribution

250 function for simulated daily mean data is corrected so that it matches the 1-km resolution 
meteorological data for Japan ${ }^{37}$. Ishizaki et al. ${ }^{24}$ demonstrated that CDFDM is superior to other methods, such as Gaussian-type scaling approaches ${ }^{38}$. Furthermore, Ishizaki et al. ${ }^{24,26}$ corrected biases in historical simulations and future projections based on the RCP2.6 and RCP8.5 scenarios for four CMIP5 GCMs (GFDL-CM3 ${ }^{39}$, MIROC $^{40}$, HadGEM2-ES ${ }^{41}$, MRI-CGCM3 ${ }^{42}$, Nor-ESM ${ }^{43}$ ) and the RCP2.6, RCP4.5, and RCP8.5 scenarios for five CMIP6 GCMs (MIROC6 ${ }^{44}$, MRI-ESM2- $0^{45}$, ACCESS-CM2 ${ }^{46}$, IPSL-CM6A-LR ${ }^{47}$, MPI-ESM1-2-HR ${ }^{48}$ ) for the Japan region at a resolution of 1 $\mathrm{km}$. Briefly, the reasons why Ishizaki et al. ${ }^{24,26}$ selected nine GCMs from the CMIP5 and CMIP6 GCMs were to cover the uncertainty ranges of future surface air temperature and precipitation projections with the models and to utilize their reproducibility in the 20th century climate.

Ishizaki et al. ${ }^{24}$ showed that bias-corrected historical climate scenarios accurately reproduced monthly averaged values; extreme values, such as summer days; and indicators defined by daily values, such as precipitation intensity. In this study, we utilized version 202005 for CMIP5 $5^{\text {Ishizaki2020 }}$ and version 202105 for $\mathrm{CMIP}^{26}$, in which the time window for the cumulative distribution function (one month) and the reference period (1980-2018) were modified so that the monthly values corresponded to those of the observations.

\section{Statistical method for inferring permafrost distribution}

268 The freezing (thawing) index, defined as the cumulative daily temperature below (above) the freezing point of $0^{\circ} \mathrm{C}$, has been used as a proxy for inferring permafrost distribution. Saito et al. ${ }^{27}$ used this index to develop a high-resolution $(2 \mathrm{~km})$ method to estimate the permafrost distribution in northeastern Asia, including the permafrost in Japanese mountainous areas investigated in the present study. Therefore, we employed the same method to infer the permafrost distribution using biascorrected, 1-km resolution climate scenarios developed by Ishizaki et al. ${ }^{24}$.

Saito et al. ${ }^{27}$ classified the permafrost area in northeastern Asia into two categories based on freezing and thawing indices: (a) CDP, which are areas where climatic conditions favour the development and/or maintenance of continuous permafrost; and (b) ECP, which are areas where the presence of permafrost is conditional upon environmental factors, such as ecosystem characteristics, topography or geology. In addition, Saito et al. ${ }^{27}$ divided seasonally frozen ground into two subcategories: (c) ground that undergoes seasonal freezing (SF) and (d) ground that undergoes intermittent freezing (IF). These distinctions were made to distinguish between seasonal frost that is deep and/or persistent and frost that exists for a short time, i.e., less than two weeks.

Using a freezing index, i.e., the number of days per year when the surface air temperature is below $0^{\circ} \mathrm{C}$ multiplied by the surface air temperature, $I_{\mathrm{f}}$, and the thawing index, i.e., the number of days per year when the surface temperature is above $0^{\circ} \mathrm{C}$ multiplied by the surface air temperature, the definition of permafrost classification is described as follows.

(a) Climate-driven permafrost: CDP 


$$
I_{t}<0.9 I_{f}-2300
$$

(b) Environmentally conditioned permafrost: ECP

$$
0.9 I_{f}-2300<I_{t}<2.4 I_{f}-3300
$$

(c) Seasonal freezing: SF

$$
2.4 I_{f}-3300<I_{t} \text { and } 30<I_{f}
$$

292 (d) Intermittent freezing: IF

$$
0<I_{f} \leq 30
$$

294 For consistency with Saito et al. ${ }^{27}$, this study uses the monthly mean surface air temperature to 295 calculate the freezing and thawing indices. Previous studies have shown that the relative error is less 296 than $5 \%$ when using daily or monthly means ${ }^{49}$. Saito et al. ${ }^{27}$ performed a permafrost classification at 297 a resolution of $2 \mathrm{~km}$ by considering the temperature decrease with altitude using spatially detailed 298 elevation data $\left(\mathrm{ETOPO} 1^{50}\right.$ ) based on the results of the CMIP5 GCMs. In the present study, a 299 temperature decrease with altitude was considered in the $1-\mathrm{km}$ mesh observational data ${ }^{37}$ used for 300 bias-corrected climate scenarios ${ }^{24,26}$.

301 In this study, the freezing and thawing indices for the past 30 years were averaged to classify the 302 permafrost in each grid, similar to Saito et al. ${ }^{27}$. Averaging over 30 years smooths the internal 303 variability in surface air temperature and corresponds to the delayed response of permafrost to 304 climate change. 


\section{References (up to 50 references)}

309 1. IPCC, 2013: Annex III: Glossary [Planton, S. (ed.)]. In: Climate Change 2013: The Physical Science Basis. Contribution of Working Group I to the Fifth Assessment Report of the Intergovernmental Panel on Climate Change [Stocker, T.F., D. Qin, G.-K. Plattner, M. Tignor, S.K. Allen, J. Boschung, A. Nauels, Y. Xia, V. Bex and P.M. Midgley (eds.)]. Cambridge University Press, Cambridge, United Kingdom and New York, NY, USA.

2. Krautblatter, M., Funk, D. \& Günzel, F. K. Why permafrost rocks become unstable: A rock-icemechanical model in time and space. Earth Surf. Proc. Land. 38, 876-887. https://doi.org/10.1002/esp.3374 (2013).

3. Lacelle, D., Brooker, A., Fraser, R. H. \& Kokelj, S. V. Distribution and growth of thaw slumps in the Richardson Mountains-Peel Plateau region, northwestern Canada. Geomorphology 235, 40-51. https://doi.org/10.1016/j.geomorph.2015.01.024 (2015).

4. Patton, A. I., Rathburn, S. L. \& Capps, D. M. Landslide response to climate change in permafrost regions. Geomorphology 340, 116-128. https://doi.org/10.1016/j.geomorph.2019.04.029 (2019).

5. Purdie, H., Gomez, C. \& Espiner, S. Glacier recession and the changing rockfall hazard: Implications for glacier tourism. N. Z. Geogr. 71, 189-202. https://doi.org/10.1111/nzg.12091 (2015).

6. Mourey, J., Marcuzzi, M., Ravanel, L. \& Pallandre, F. Effects of climate change on high Alpine mountain environments: Evolution of mountaineering routes in the Mont Blanc massif (Western Alps) over half a century. Arct. Antarct. Alp. Res. 51, 176-189. https://doi.org/10.1080/15230430.2019.1612216 (2019).

7. Shen, Y.-J. et al. Trends and variability in streamflow and snowmelt runoff timing in the southern Tianshan Mountains. J. Hydrol. 557, 173-181. https://doi.org/10.1016/j.jhydrol.2017.12.035 (2018).

8. Trujillo, E., Molotch, N. P., Goulden, M. L., Kelly, A. E. \& Bales, R. C. Elevation-dependent influence of snow accumulation on forest greening. Nat. Geosci. 5, 705-709. https://doi.org/10.1038/ngeo1571 (2012).

9. Sloat, L. L., Henderson, A. N., Lamanna, C. \& Enquist, B. J. The effect of the Foresummer drought on carbon exchange in subalpine meadows. Ecosystems 18, 533-545. https://doi.org/10.1007/s10021-015-9845-1 (2015).

10. Jones, D. B., Harrison, S., Anderson, K. \& Betts, R. A. Mountain rock glaciers contain globally significant water stores. Sci. Rep. 8, 2834. https://doi.org/10.1038/s41598-018-21244-w (2018).

11. Kubo, T., Shoji, Y., Tsuge, T. \& Kuriyama, K. Voluntary contributions to hiking trail maintenance: Evidence from a field experiment in a National Park, Japan. Ecol. Econ. 144, 124-128 (2018). 
12. Yokohata, T. et al. Future projection of greenhouse gas emissions due to permafrost degradation using a simple numerical scheme with a global land surface model. Prog. Earth Planet Sci. 7, 56. https://doi.org/10.1186/s40645-020-00366-8 (2020).

13. Obu, J. et al. Northern Hemisphere permafrost map based on TTOP modelling for 2000-2016 at 1 km2 scale. Earth-Science Reviews 193, 299-316, doi:https://doi.org/10.1016/j.earscirev.2019.04.023 (2019).

14. Ishikawa, M. \& Hirakawa, K. Mountain permafrost distribution based on BTS measurements and DC resistivity soundings in the Daisetsu Mountains, Hokkaido, Japan. Permafrost Periglac. Process. 11, 109-123. https://doi.org/10.1002/099-1530(200004/06)11:2<109::AIDPPP343>3.0.CO;2-O (2000).

15. Higuchi, K. \& Fujii, Y. Permafrost at the summit of Mount Fuji, Japan. Nature 230, 521-521. https://doi.org/10.1038/230521a0 (1971).

16. Ikeda, A. et al. Year-round Monitoring of Shallow Ground Temperatures at High Altitudes of Mt. Fuji with a Critical Discussion on the Popular Belief of Rapid Permafrost Degradation. J. Geogr. 121, 306-331 (2012).

17. Fukui, K. \& Iwata, S. Result of permafrost investigation in Kuranosuke Cirque, ateyama, the Japanese Alps. Snow Ice 62, 23-28 (2000).

18. Aoyama, M. Rock glaciers in the northern Japanese Alps: Palaeoenvironmental implications since the Late Glacial. J. Quat. Sci. 20, 471-484 (2005).

19. Schneider von Deimling, T. et al. Observation-based modelling of permafrost carbon fluxes with accounting for deep carbon deposits and thermokarst activity. Biogeosciences 12, 34693488. https://doi.org/10.5194/bg-12-3469-2015 (2015).

20. Chadburn, S. E. et al. An observation-based constraint on permafrost loss as a function of global warming. Nat. Clim. Change 7, 340-344. https://doi.org/10.1038/nclimate3262 (2017).

21. Gasser, T. et al. Path-dependent reductions in $\mathrm{CO} 2$ emission budgets caused by permafrost carbon release. Nat. Geosci. 11, 830-835. https://doi.org/10.1038/s41561-018-0227-0 (2018).

22. Yokohata, T. et al. Future projection of greenhouse gas emissions due to permafrost degradation using a simple numerical scheme with a global land surface model. Prog. Earth Planet Sci. 7, 56. https://doi.org/10.1186/s40645-020-00366-8 (2020).

23. Hock, R. et al. High Mountain Areas. In: IPCC Special Report on the Ocean and Cryosphere in a Changing Climate [H.-O. Pörtner, D.C. Roberts, V. Masson-Delmotte, P. Zhai, M. Tignor, E. Poloczanska, K. Mintenbeck, A. Alegría, M. Nicolai, A. Okem, J. Petzold, B. Rama, N.M. Weyer (eds.)]. (2019)

24. Ishizaki, N. N. et al. Evaluation of two bias-correction methods for gridded climate scenarios over Japan. SOLA 16, 80-85. https://doi.org/10.2151/sola.2020-014 (2020). 
25. Yokohata, T. et al. Projections of surface air temperature required to sustain permafrost and importance of adaptation to climate change in the Daisetsu Mountains, Japan. Scientific Reports 11, 15518, doi:10.1038/s41598-021-94222-4 (2021).

26. Ishizaki, N. N. Bias corrected climate scenarios over Japan based on CDFDM method using CMIP6, doi:10.17595/20210501.001

27. Saito, K. et al. Evaluation of LPM permafrost distribution in NE Asia reconstructed and downscaled from GCM simulations. Boreas 43, 733-749. https://doi.org/10.1111/bor.12038 (2014).

28. Iwahana, G. et al. Monitoring of Permafrost in the Daisetsu Mountains 2005-2010, JSSI \& JSSE Joint Conference, Nagaoka, Niigata, https://doi.org/10.14851/jcsir.2011.0.88.0 (2011)

29. Fukuda, M. \& Sone, T. Some Characteristics of Alpine Permafrost, Mt. Daisetsu, Central Hokkaido, Northern Japan. Geografiska Annaler: Series A, Physical Geography 74, 159-167, doi:10.1080/04353676.1992.11880359 (1992).

30. Sone, T. \& Watanabe, T. Lower limit of permafrost distribution on the wind-beaten bare ground in the Daisetsu Mountains, Hokkaido Proceedings of the General Meeting of the Association of Japanese Geographers, No.93, p87. https://doi.org/10.14866/ajg.2018s.0_000320 (2018)

31. Sone, T., Ground surface temperatures on the windward bare ground in the Daisetsu Mountains. JSSI \& JSSE Joint Conference on Snow and Ice Research (2020).

32. Iwahana, G. et al. Geomorphological and geochemistry changes in permafrost after the 2002 tundra wildfire in Kougarok, Seward Peninsula, Alaska. J. Geophys. Res. Earth Surf. 121, 1697-1715. https://doi.org/10.1002/2016jf003921 (2016).

33. Abe, T. et al. Surface displacement revealed by L-band InSAR analysis in the Mayya area, Central Yakutia, underlain by continuous permafrost. Earth Planets Space 72, 138. https://doi.org/10.1186/s40623-020-01266-3 (2020).

34. Iizumi, T., Nishimori, M., Ishigooka, Y. \& Yokozawa, M. Introduction to climate change scenario derived by statistical downscaling. J. Agric. Meteorol. 66, 131-143. https://doi.org/10.2480/agrmet.66.2.5 (2010).

35. Iizumi, T., Nishimori, M., Dairaku, K., Adachi, S. A. \& Yokozawa, M. Evaluation and intercomparison of downscaled daily precipitation indices over Japan in present-day climate: Strengths and weaknesses of dynamical and bias correction-type statistical downscaling methods. J. Geophys. Res. Atmos. https://doi.org/10.1029/2010jd014513 (2011).

36. Iizumi, T. et al. Future change of daily precipitation indices in Japan: A stochastic weather generator-based bootstrap approach to provide probabilistic climate information. J. Geophys. Res. Atmos. https://doi.org/10.1029/2011jd017197 (2012). 
37. Ohno, H., Sasaki, K., Ohara, G. \& Nakazono, K. O. U. Development of grid square air temperature and precipitation data compiled from observed, forecasted, and climatic normal data. Clim. Biosphere 16, 71-79. https://doi.org/10.2480/cib.J-16-028 (2016).

38. Haerter, J. O., Hagemann, S., Moseley, C. \& Piani, C. Climate model bias correction and the role of timescales. Hydrol. Earth Syst. Sci. 15, 1065-1079. https://doi.org/10.5194/hess-151065-2011 (2011).

39. Donner, L. J. et al. The dynamical core, physical parameterizations, and basic simulation characteristics of the atmospheric component AM3 of the GFDL global coupled model CM3. J. Clim. 24, 3484-3519. https://doi.org/10.1175/2011jcli3955.1 (2011).

40. Watanabe, M. et al. Improved climate simulation by MIROC5: Mean states, variability, and climate sensitivity. J. Clim. 23, 6312-6335. https://doi.org/10.1175/2010jcli3679.1 (2010).

41. Jones, C. D. et al. The HadGEM2-ES implementation of CMIP5 centennial simulations. Geosci. Model Dev. 4, 543-570. https://doi.org/10.5194/gmd-4-543-2011 (2011).

42. Yukimoto, S. et al. A new global climate model of the meteorological research institute: MRICGCM3-Model description and basic performance. J. Meteorol. Soc. Jpn. Ser. 90A, 23-64. https://doi.org/10.2151/jmsj.2012-A02 (2012).

43. Bentsen, M. et al. The Norwegian earth system model, NorESM1-M-Part 1: Description and basic evaluation of the physical climate. Geosci. Model Dev. 6, 687-720. https://doi.org/10.5194/gmd-6-687-2013 (2013).

44. Tatebe, H. et al. Description and basic evaluation of simulated mean state, internal variability, and climate sensitivity in MIROC6. Geosci. Model Dev. 12, 2727-2765, doi:10.5194/gmd-122727-2019 (2019).

45. Yukimoto, S. et al. The Meteorological Research Institute Earth System Model Version 2.0, MRI-ESM2.0: Description and Basic Evaluation of the Physical Component. Journal of the Meteorological Society of Japan, doi:10.2151/jmsj.2019-051 (2019).

46. Bi, D. et al. Configuration and spin-up of ACCESS-CM2, the new generation Australian Community Climate and Earth System Simulator Coupled Model. Journal of Southern Hemisphere Earth Systems Science 70, 225-251, doi:https://doi.org/10.1071/ES19040 (2020).

47. Boucher, O. et al. Presentation and Evaluation of the IPSL-CM6A-LR Climate Model. Journal of Advances in Modeling Earth Systems 12, e2019MS002010, doi:https://doi.org/10.1029/2019MS002010 (2020)

48. Müller, W. A. et al. A Higher-resolution Version of the Max Planck Institute Earth System Model (MPI-ESM1.2-HR). Journal of Advances in Modeling Earth Systems 10, 1383-1413, doi:https://doi.org/10.1029/2017MS001217 (2018). 
447

448

449

450

451

452

453
49. Frauenfeld, O. W., Zhang, T. \& Mccreight, J. L. Northern Hemisphere freezing/thawing index variations over the twentieth century. Int. J. Climatol. 27, 47-63. https://doi.org/10.1002/joc.1372 (2007).

50. Amante, C. \& Eakins, B. W. ETOPO1 1 arc-minute global relief model: Procedures, data sources and analysis. NOAA Technical Memorandum NESDIS NGDC-24 (2009) 


\section{Supplementary Files}

This is a list of supplementary files associated with this preprint. Click to download.

- YokohataetalPermafrostJP20210906.SI.pdf 